\title{
Occurrence of shiga toxin-producing Escherichia coli carrying antimicrobial resistance genes in sheep on smallholdings in Bangladesh
}

\author{
Mukta Das Gupta ${ }^{1}$, Arup Sen ${ }^{1}$, Mishuk Shaha ${ }^{2}$, Avijit Dutta ${ }^{1}$ and Ashutosh Das ${ }^{2, *}$ \\ 1 Department of Microbiology and Veterinary Public Health, Faculty of Veterinary Medicine, Chittagong \\ Veterinary and Animal Sciences University, Khulshi, Chittagong-4225, Bangladesh \\ 2 Department of Genetics and Animal Breeding, Faculty of Veterinary Medicine, Chittagong Veterinary and \\ Animal Sciences University, Khulshi, Chittagong-4225, Bangladesh \\ * Correspondence: ashutosh.das@cvasu.ac.bd; Tel.: +8801675725800
}

\begin{abstract}
Inappropriate antimicrobial treatment can pose a risk for developing resistance against antimicrobial drugs in bacteria. Close human contact might have a higher chance of being transmitted to humans from sheep if the sheep population is a potential reservoir of zoonotic pathogens such as shiga toxin-producing Escherichia coli (E. coli) (STEC). Therefore, this study aimed to examine the sheep population in rural Bangladesh for antimicrobial resistant STEC. We screened 200 faecal samples collected from sheep in three Upazila from the Chattogram district. Phenotypically positive E. coli isolates were examined for two shiga toxin-producing genes - st $x 1$ and st $x 2$. PCR positive STEC isolates were investigated for the presence of antimicrobial resistance genes- blaтем, sul1 and sul2. In total, 123 of the 200 tested samples were confirmed positive E. coli by cultured based methods. PCR results show 17(13.8\%) E. coli isolates harboured $\geq$ one virulent gene (stx 1 or/and st $x 2$ ) of STEC. Six of the tested STEC isolates exhibited blaTEM gene; eight STEC isolates had sul1 gene, and sul2 gene was detected in ten STEC isolates. To our knowledge, this study is the first to reveal a significant proportion of STEC isolated from sheep in rural Bangladesh harbouring antimicrobial resistance genes.
\end{abstract}

Keywords: Sheep; E. coli; shiga-toxin; antimicrobial resistance genes

\section{Introduction}

The use of antimicrobial drugs in food-producing animals can lead to antimicrobial resistance $(A M R)$ in foodborne pathogens. AMR in pathogens can be monitored by resistance in the key species of AMR, E. coli [1]. E. coli is an asymptomatic intestinal inhabitant in food-producing animals. Some E. coli variant can cause diarrhoeal disease and extra-intestinal infections by expressing several specific virulence factors, are known as pathogenic E. coli [2-4].

Shiga toxin-producing E. coli (STEC) is a pathogenic E. coli strain which can cause severe illness in human including life-threatening hemolytic uremic syndrome (HUS) [5]. Approximately three-quarters of reported STEC infections in human is attributed to domestic ruminant [6]. Cattle and other ruminants such as sheep and goat are considered the most common reservoirs of STEC. This pathogen can be transmitted to human via direct contact with infected animal, but foods (meat, milk and beverages or water) contaminated with fecal material is considered as the main route of transmission [7-10].

Pathogenic strains of E. coli are becoming increasingly resistant by acquiring resistance genes derived from conjugative plasmids. E. coli can spread this resistance to other enteric bacteria such as salmonella and campylobacter [11]. In recent years, a widespread resistance to various antimicrobial in E. coli reported in humans and non-human sources [12]. In addition, the recent focus on 'One Health' aspects of AMR, surveillance for antimicrobial resistant E. coli in animal become more crucial to explore the extend of 
public health risk posed by pathogens of zoonotic origin. Monitoring of the occurrence of AMR in STEC in healthy animal may measure the spread of resistant strains and resistance genes from animal to humans, hence, crucial for revise and implementation of new control measures for antibiotic resistance.

In Bangladesh, previous studies reported the prevalence of STEC in various livestock species [13-16]. However, there is no report on the prevalence of STEC in sheep. In addition, there is no Bangladeshi study investigate the antibiotic resistance at gene level. Taken together the current study aimed to determine the antibiotic resistance genes and explore the prevalence of STEC from fecal samples of healthy sheep in Bangladesh. E. coli isolates were screened for the presence of major virulence genes: st 1 and st $x 2$ and the presence of three antimicrobial resistance genes- blaTEM, sul1 and sul2 were determined.

\section{Results}

\subsection{Prevalence of and STEC}

A total of 200 bacterial isolates were recovered from sheep faecal samples. From the 200 recovered bacteria, by the conventional method, 144 (72\%) of the total recovered isolates were suspected as $E$. coli through their phenotypical characteristics on agar (pinkcoloured colonies on MacConkey agar). Of the 144 MacConkey positive isolates, 123 were confirmed conventionally as E. coli by EMB agar. Among the total 123 E. coli isolates, 17 $(13.8 \%)$ were characterized by PCR as having one or both stx 1 , st $x 2$ virulence genes. Therefore, the prevalence of STEC isolates that carried at least one virulence gene in the total study population could be $8.5 \%$ (95\% CI 5.3 to 13.3 ).

\subsection{Diversity of identified STEC}

PCR results of some isolates representing amplicons of stx 1 and stx 2 genes are depicted in Figure 1. PCR results showed that $10(8.9 \%)$ isolates were positive for the stx 1 , and $6(5.69 \%)$ of the E. coli isolates possessed only the stx 2 gene. One isolate was found positive for both st $x 1$ and st $x 2$ genes. The prevalence of STEC possessing the virulent gene stx 1 and stx2 was $5.0 \%$ (95\% CI 2.63 to 9.07 ) and $3.0 \%$ (95\% CI 1.23 to 6.54) respectively in the study population. Only one isolate [0.5\%, (95\% CI 0.00 .01 to 0.306)] possessed the combination of both stx 1 and stx 2 genes.

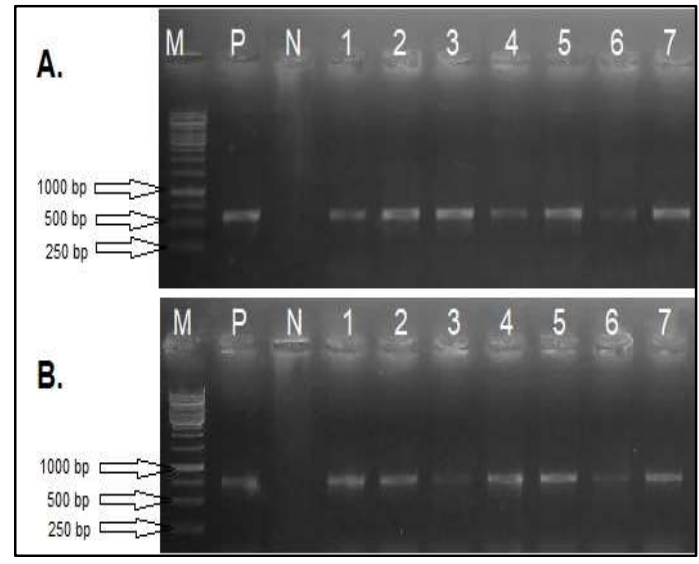

Figure 1. Results of PCR assay for two shiga toxin producing genes: stx 1 and st $x 2$. A. st $x 1$ gene (614 bp) amplicon: lane $\mathrm{M}=1 \mathrm{~kb}$ plus DNA ladder, lane $\mathrm{P}$, Positive control, lane $\mathrm{N}$, Negative control, lanes 1-7, stx1-positive isolates; B. st 2 gene (779 bp) amplicon: lane $\mathrm{M}=1 \mathrm{~kb}$ plus DNA ladder; lane $\mathrm{P}$, Positive control, N=Negative control, lanes 1-7, st $x 2$-positive isolates. 
The prevalence of STEC isolates possessing the stx 1 gene was not varied between the variables - age, breed, sex, health status, and previous history of using any antibiotics. However, a higher isolation rate is observed in adult than in lamb ( $\mathrm{P}=0.3572)$ (Table S1), although the isolation rate was not statistically significant. Male had a relatively higher isolation rate of stx 2 genotype than female sheep, but statistically insignificant $(\mathrm{P}=0.4726)$. The prevalence of st 2 genotype in sheep population not varied significantly between variables studied, but a higher isolation rate was observed in sheep reared in the free-range system than semi-intensive system and fair than healthy sheep (Table S2).

\subsection{Antimicrobial susceptibility patterns of the STEC isolates}

The antimicrobial susceptibility of the 17 STEC isolates that contained at least one Shiga toxin-producing gene (stx 1 and st $x 2$ ) were tested to 10 different agents. The numbers of isolate sensitive, intermediately resistant and resistant to the antimicrobials tested are shown in Figure 2. Of the tested isolates, $82 \%, 76 \%, 71 \%$ and $71 \%$ were sensitive to chloramphenicol, gentamicin ciprofloxacin and ampicillin, respectively; $47 \%$ isolates were resistant to trimethoprim-sulfamethoxazole, and $41 \%$ were resistant to amoxicillin.

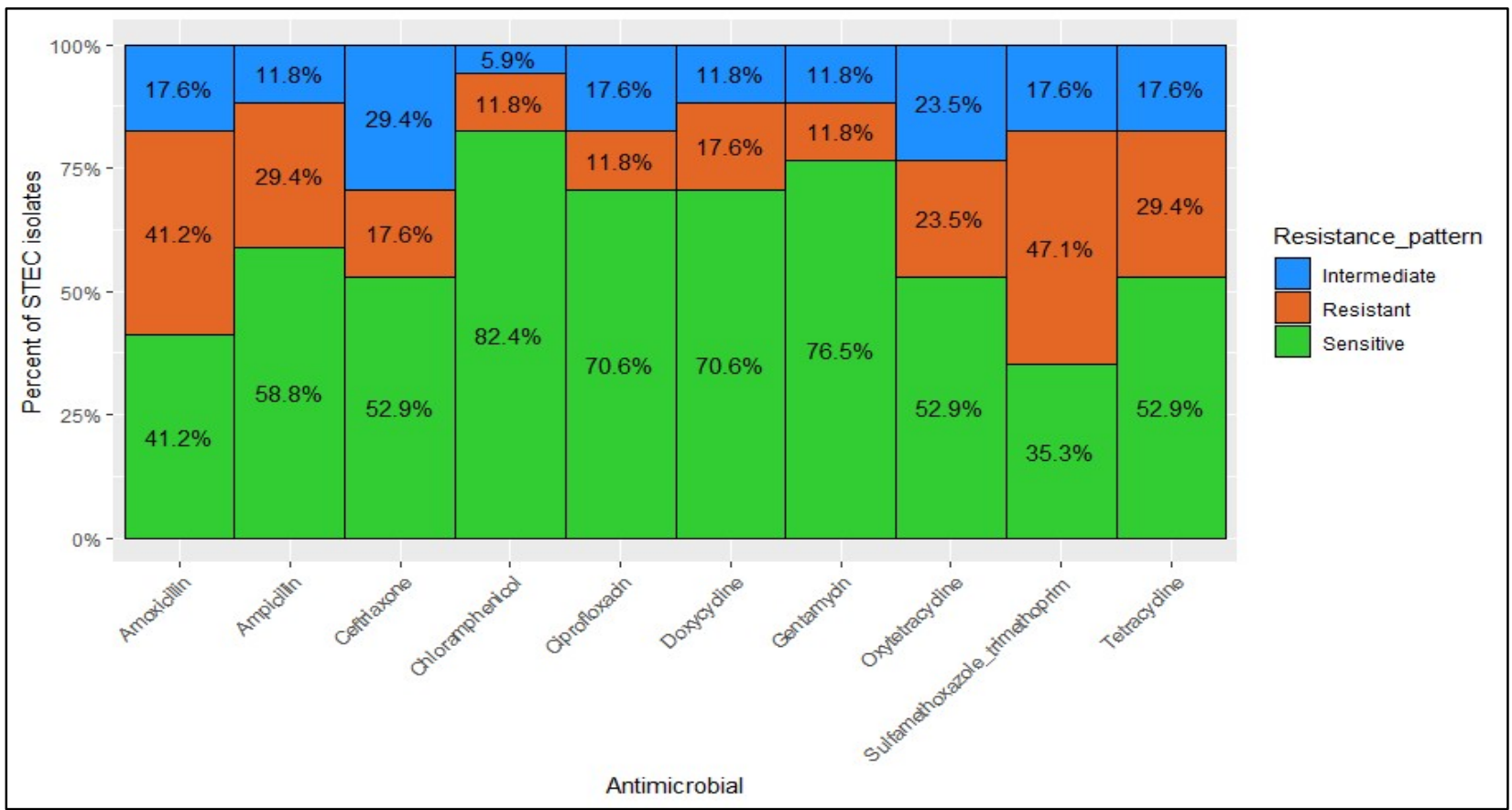

Figure 2. Antimicrobial resistance pattern in shiga toxin-producing Escherichia coli isolated from sheep in Bangladesh.

The antimicrobial susceptibility profiles of st 1 and st $x 2$ genotypes are displayed in Table 1 . Five $(50 \%)$ and $4(40 \%)$ of the st 1 genotypes tested were resistant to trimethoprim-sulfamethoxazole and amoxicillin, respectively; $50 \%$ of the st 2 genotypes were resistant to trimethoprim-sulfamethoxazole. Ampicillin, amoxicillin and Ceftriaxone were resistant to $33.33 \%$ of st $x 2$ positive isolates. One isolate that harboured st $x 1$ and st $x 2$ genes was $100 \%$ resistant to tetracycline, amoxicillin, and oxytetracycline. 
Table 1. Frequencies of st $x 1$ and stx 2 genotypic isolates of Escherichia coli resistant to the antimicrobials tested

\begin{tabular}{|c|c|c|c|}
\hline \multirow[t]{2}{*}{ Antimicrobial } & \multicolumn{3}{|c|}{ No. resistant isolates $(\%)$} \\
\hline & $\operatorname{stx} 1(\mathrm{n}=10)$ & $s t x 2(\mathrm{n}=6)$ & $s t x 1+s t x 2(1)$ \\
\hline CRO & $2(20 \%)$ & $2(33.33 \%)$ & 0 \\
\hline CIP & $1(10 \%)$ & $1(16.67 \%)$ & 0 \\
\hline TET & $3(30 \%)$ & $1(16.67 \%)$ & $1(100 \%)$ \\
\hline AMP & $3(30 \%)$ & $2(33.33 \%)$ & 0 \\
\hline DOC & $2(20 \%)$ & $1(16.67 \%)$ & 0 \\
\hline SXT & $5(50 \%)$ & $3(50 \%)$ & 0 \\
\hline GNT & $1(10 \%)$ & $1(16.66 \%)$ & 0 \\
\hline CHL & $2(20 \%)$ & $0(0 \%)$ & 0 \\
\hline AML & $4(40 \%)$ & $2(33.33 \%)$ & $1(100 \%)$ \\
\hline OXT & $2(20 \%)$ & $1(16.67 \%)$ & $1(100 \%)$ \\
\hline
\end{tabular}

CRO, Ceftriaxone; CIP, Ciprofloxacin; TET, Tetracycline; AMP, Ampicillin; DOC, Doxycycline; SXT, Sulfamethoxazole-Trimethoprim; GNT, Gentamycin; CHL, Chloramphenicol; AML, Amoxycillin and OXT, Oxytetracycline.

\subsection{Proportion of STEC isolates carrying resistance genes}

PCR for antimicrobial-resistance genes revealed six (35\%) of the 17 STEC isolates carried blaTEM gene. Eight (47\%) and 10 (59\%) STEC isolates were positive for sul1 and sul2 genes, respectively (Figure 3). The clean and curated sequences for blaTEM, sul1 and sul2 genes were deposited in nucleotide database in NCBI Genbank under accession no. MN622888, MN401416 and MN401417, respectively. BLAST search detected a high sequence similarity (99-100\%) between the partially sequenced resistance genes in this study and published blaтем, sul1 and sul2 gene sequences (GenBank Accession Number: KJ923008, AB733642 and GU256641, respectively).

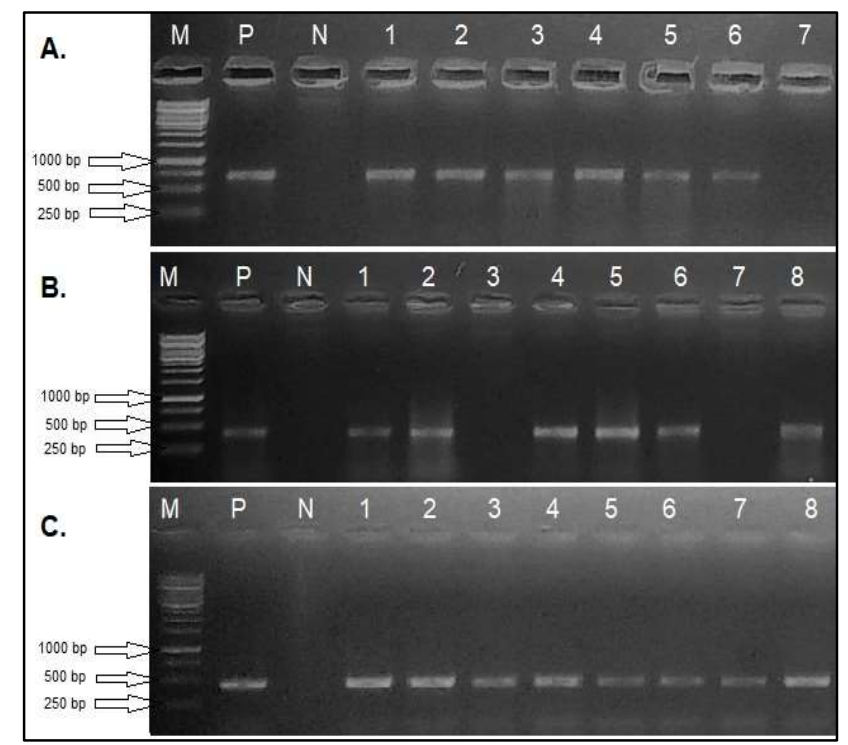

Figure 3. Results of PCR assay for three antimicrobial resistance genes: blaTEM, sul1 and sul2. A. blaTEM gene (716 bp) amplicon: lane $\mathrm{M}=1 \mathrm{~kb}$ plus DNA ladder, lane P, Positive control, lane N, Negative control, lanes 1-7, blaтем-positive isolates; B. sul1 gene (433 bp) amplicon: lane $\mathrm{M}=1 \mathrm{~kb}$ plus DNA ladder; lane P, Positive control, N=Negative control, lanes 1-8, sul1-positive isolates; C. sul2 gene (433 bp) amplicon: lane $\mathrm{M}=1 \mathrm{~kb}$ plus DNA ladder; lane $\mathrm{P}$, Positive control, $\mathrm{N}=$ Negative control, lanes 1-8, sul2-positive isolates. 


\section{Discussion}

The study investigates the molecular characterization of STEC strains in sheep of Bangladesh and the presence of antimicrobial resistance genes in STEC. This is the first longitudinal study of STEC performed on sheep of Bangladesh to the authors' knowledge. The results of the study revealed that out of 200 samples, all the 144 isolates, as evidenced by the production of large pink-coloured colonies (a selective medium recommended for E. coli), were probably not E. coli since only 123 were found to be E. coli as they produced metallic green sheen on EMB agar.

The present study observed $8.5 \%$ sheep on smallholding in Bangladesh could be reservoir of STEC. This is more or less similar to the findings of our previous studies, Gupta et al., (2018) and Gupta et al., (2016), where we observed 7\% and 6.2\% of healthy buffalo and goa in Bangladesh carry STEC [13, 14]. Islam et. al., (2015) also reported a similar prevalence $(7.5 \%)$ of probable EHEC O157 circulating in smallholders' cattle [16]. However, a higher prevalence rate $(16.2 \%)$ among healthy goat in Spain was reported by Orden et al. [17]. A study on sheep in Switzerland recorded 29.9\% of slaughtered sheep carry STEC [18]. Zschock et al. (2000) recorded a 32\% prevalence of STEC in German sheep [19]. In contrast, lower prevalence was reported in UK and Saudi Arabia [20, 21]. Differences observed in the proportion of STEC genotypes in sheep rectal swab samples tested in this study and others performed elsewhere were possibly because of differences in husbandry practices, agro-climatic variations, sampling, methods of detection, breeds and the age of animals $[22,23]$. However, proportions of sheep carrying STEC between the different variables did not differ significantly. Similar husbandry practice for sheep in sampled smallholdings might be the reason for this.

The STEC strains isolated from sheep in this study were genetically diverse based on their possession of virulent genes. PCR assays showed that $13.8 \%$ E. coli isolates (17 in 123) possess $\geq 1$ of the two virulent genes studied - st $x 1$ and st $x 2$. Wani et al., (2006) showed that $13.45 \%$ (37 in 275) isolates harboured at least one virulent gene in Indian goat tested for stx1, stx2, hly and eae [24]. Islam et al., (2015) showed that 5.98\% of isolates (31 in 518) from faecal samples of smallholders' cattle in Bangladesh carried at least one virulent gene- stx 1 , stx 2 and hly [16]. Ten (8.9\%) E. coli isolates were positive for Shiga toxin-producing $E$. coli gene stx 1 . The percentage of st $x 1$ carriage in E. coli isolated from Bangladeshi Buffalo was also found similar (Gupta et al., 2018). A slightly higher prevalence (15.9\%) of stx1 was observed in Irish sheep [25]. Gupta et al. (2016) and Wani et al. (2006) also detected that a higher proportion of $E$. coli isolated from goat could harbour the stx 1 gene. Seven (3.5\%) E. coli positive samples were tested positive for the presence of stx2 genes by PCR. MaCarthy et al., (2019) reported a higher prevalence of stx2 virulent factor in isolates from Irish sheep [25]. E. coli isolated from Bangladeshi Buffalo and cattle observed with a similar prevalence of the st $x 2$ gene. However, goat isolates in Bangladesh carry more stx2 than sheep isolates in the present study [13].

In the present study, we observed a diverse antimicrobials resistance pattern in STEC isolates. The occurrence of Multidrug resistance (MDR) STEC in sheep in the present study is corroborated by other studies $[14,26]$. The finding is indicative of a selective pressure of several groups of antimicrobial substances on the farm related to treatment sometime in the past. The present study observed a higher rate resistance of STEC to sulfamethoxazole, tetracycline, oxytetracyclin, ampicillin and amoxicillin, an agreement with some previous reports $[27,28]$. STEC isolates showed a higher sensitivity to chloramphenicol, gentamycin, ciprofloxain and doxycyclin. This finding agrees with the study on STEC in buffaloes and goat of Bangladesh [14, 27]. These observations warrant more clinical trials to identify whether chloramphenicol, gentamycin, ciprofloxain and doxycyclin are the choice of antibiotics in the control of STEC infection in animals and human in Bangladesh. 
Seven isolates showed either intermediate or complete resistance to ampicillin in disk diffusion test, six of them were positive for BLATEM gene by PCR. Eleven STEC isolates were recorded with either intermediate or complete resistance to sulfamethoxazole-trimethoprim, of which 10 were positive for sul1 gene and 8 were positive for sul2 gene. There were minor differences between the number of resistant STEC based on disk diffusion method and molecular identification. However, molecular detection of known antimicrobial resistance genes considered to have increased sensitivity and specificity [29].

The detection of antibiotic resistance genes in the present study signifies that there is a risk of spread of the antimicrobial resistance to human by direct or indirect transmission of resistant isolates through food, water, mud, and manure [30]. At least of a transmission of multi-resistance encoding determinants from coliform bacteria of food animal origin to human strains, may take place, if sanitary regulations are not observed [31]. These resistant $E$. coli isolates can also rapidly spread the resistance to other species of bacteria by horizontal gene transfer (HGT) [32].

\section{Materials and Methods}

\subsection{Sample collection, Culture and isolation}

A total of 200 fecal samples were collected from sheep from three upazilas (a upazila is a subdistrict level area) of Southeastern Bangladesh. The samples were collected from apparently healthy sheep of all ages, sexes, and breeds on smallholder farms. Fecal materials from each animal were collected by inserting a sterile cotton swab into recto-anal junction. After collection, swabs were dipped into buffered peptone water and stored in an icebox (4oC). Collected swabs were shipped immediately to the Microbiology and Veterinary Public Health Laboratory, Chittagong Veterinary and Animal Sciences University.

A presumptive E. coli isolate was identified based on the growths in selective media, as described previously [14,33]. Briefly, a sample in buffered peptone water was incubated at $37^{\circ} \mathrm{C}$ for $24 \mathrm{~h}$ in an incubator for enrichment. Each enriched sample was streaked onto MacConkey agar (Oxoid) and the plate incubated at $37^{\circ} \mathrm{C}$ for $24 \mathrm{~h}$. Five well isolated bright pink colonies MacConkey agar subcultured onto tryptic soy broth (TSB), incubated at $37^{\circ} \mathrm{C}$ for $6 \mathrm{~h}$ in a shaker incubator. Growths from TSB were again inoculated on the MacConkey agar and five cross-sectional colonies from homogenous pink colonies were then onto an Eosin Methylene Blue (EMB, Oxoid) agar plate, incubated at $37^{\circ} \mathrm{C}$ for $24 \mathrm{~h}$ to examine the characteristic metallic green sheen produced by E. coli. An isolate producing green colonies with a metallic sheen on EMB agar was confirmed as E. coli. All confirmed E. coli isolated were preserved at $-80^{\circ} \mathrm{C}$ in LB broth with $15 \%$ glycerin until assessment for virulence genes.

\subsection{Detection of Shiga toxin-producing genes}

Total DNA was extracted from confirmed E. coli isolates using a boiling method. All isolates were evaluated for the presence of the shiga toxin-producing genes (st $x 1$, st $x 2)$ using PCR amplification. The details of primers and PCR products are presented in Table 2. PCR amplification of was performed in a volume of $50 \mu \mathrm{l}$ containing $1 \mu \mathrm{l}$ of the prepared DNA template; $1 \mu \mathrm{l}$ (each) primer at $20 \mathrm{pmol}, 5 \mu \mathrm{l}$ of $20 \mathrm{mM}$ magnesium chloride, $1 \mu \mathrm{l}$ of $\mathrm{dNTP}(40 \mathrm{nM}), 0.2 \mu \mathrm{l}$ Dream Taq DNA polymerase $(0.4 \mathrm{U} / \mu \mathrm{l})$ (Thermo Scientific, Fermentas International Inc., USA) and $40.8 \mu \mathrm{l}$ molecular grade water. Each reaction volume was processed using a Thermo-cycler (2720 Thermal cycler, Applied Biosystems, USA) at $95^{\circ} \mathrm{C}$ for $3 \mathrm{~min}$ (initial denaturation), followed by 35 cycles at $95^{\circ} \mathrm{C}$ for $30 \mathrm{sec}$ (denaturation), annealing temperature (specific for each primer) for $40 \mathrm{sec}$ (binding), and at $72{ }^{\circ} \mathrm{C}$ for 1 
min (extension). Final extension was performed at $72^{\circ} \mathrm{C}$ for $8 \mathrm{~min}$. An aliquot of the reaction mixture without template DNA was used as a negative control. A STEC strain isolated by Gupta et al, (2016) [ 13] was utilized as a positive control.

Table 2. Oligonucleotide primer sequences for st 1 and stx 2 genes, annealing temperature, size of the PCR product, and reference of each primer used.

\begin{tabular}{llllll}
\hline Primer & Primer Sequence $\left(5^{\prime}-\mathbf{3}^{\prime}\right)$ & $\begin{array}{l}\text { Target } \\
\text { gene }\end{array}$ & $\begin{array}{l}\text { Annealing } \\
\text { temp. }\left({ }^{\circ} \mathbf{C}\right)\end{array}$ & $\begin{array}{l}\text { Amplicon } \\
(\mathbf{b p})\end{array}$ & References \\
\hline stx1 F & $\begin{array}{l}\text { ACA CTG GAT GAT CTC AGT GG } \\
\text { stx1 R }\end{array}$ & CTG AAT CCC CCT CCA TTA TG & 58 & 614 & {$[34]$} \\
stx2 F & CCA TGA CAA CGG ACA GCA GTT & stx2 & 58 & 779 & {$[35]$} \\
stx2 R & CCT GTC AAC TGA GCA GCA CTT T & & & & \\
\hline
\end{tabular}

\subsection{Antimicrobial susceptibility}

Antimicrobial susceptibility profile of STEC isolates was determined by disc diffusion method [36] following Clinical and Laboratory Standards Institute's (CLSI) guidelines. Commercial discs (Oxoid, UK) for ten antimicrobials were used: Amoxicillin (AML, $10 \mu \mathrm{g}$ ), ampicillin (AMP, $10 \mu \mathrm{g}$ ), ceftriaxone (CRO, $30 \mu \mathrm{g}$ ), chloramphenicol (CHL, $30 \mu \mathrm{g}$ ), ciprofloxacin (CIP, $5 \mu \mathrm{g})$, doxycycline (DOX, $30 \mu \mathrm{g})$, gentamicin $(\mathrm{CN}, 10 \mu \mathrm{g})$, Oxytetracycline (OTE, $30 \mu \mathrm{g}$ ), trimethoprim/sulfamethoxazole (SXT, $30 \mu \mathrm{g}$ ) and tetracycline (TE, 30 $\mu \mathrm{g})$.

The susceptibility pattern was designated as "sensitive", "intermediate" and "resistant" based on inhibitory zone and comparing with the standard chart from the CLSI.

\subsection{PCR assays and sequencing of antibiotic resistance genes}

STEC isolates were screen for the presence of three antimicrobial resistance geneblaTEM (ampicillin), sul1 and sul2 (sulfonamide). Uniplex PCR assay was used for the identification of each resistance gene. PCR amplification was performed using primers and cycle conditions described in the relevant literature (Table 3). The rection volume for each PCR assay was $50 \mu \mathrm{l}$ containing similar proportions as described in the "detection of Shiga toxin-producing genes" section of this article.

One amplified and cleaned PCR product for each resistance gene was sequenced bidirectionally using BigDye Terminator v. 3.1 (ThermoFisher Scientific, Waltham, MA, USA) cycle sequencing protocol by Macrogen Co., Korea. To detect sequence similarity, the sequences were compared to the nucleotide database in NCBI Genbank using BLAST [37].

Table 3. Oligonucleotide primer sequences for blaтем, sul1 and sul2 genes, annealing temperature, size of the PCR product, and reference of each primer used.

\begin{tabular}{cccccc}
\hline Primer & Primer Sequence $\left(5^{\prime}-\mathbf{3}^{\prime}\right)$ & Target gene & $\begin{array}{c}\text { Annealing } \\
\text { temp. }\left({ }^{\circ} \mathbf{C}\right)\end{array}$ & $\begin{array}{c}\text { Amplicon } \\
(\mathbf{b p})\end{array}$ & References \\
\hline blatem F & TAC GAT ACG GGA GGG CTT AC & blatem & 60 & 716 & {$[38]$} \\
blaтем R & TTC CTG TTT TTG CTC ACC CA & & & & \\
sul1 F & CGG CGT GGG CTA CCT GAA CG & sul1 & 51 & 433 & {$[39]$} \\
sul1 R & GCC GAT CGC GTG AAG TTC CG & & & & \\
sul2 F & CCT GTT TCG TCC GAC ACA GA & sul2 & 59 & 435 & {$[40]$} \\
sul2 R & GAA GCG CAG CCG CAA TTC AT & & & & \\
\hline
\end{tabular}




\subsection{Statistical analysis}

All data were entered into a spreadsheet programme (Excel 2010, Microsoft Corporation). The prevalence of probable STEC with $95 \%$ confidence interval and the difference between variables for the presence of $s t x 1$ and stx 2 genes in the probable STEC isolates was shown using a $\chi 2$ test. All statistical analyses were performed by using GraphPad Prism version 7.00 for Windows, GraphPad Software, La Jolla California USA, www.graphpad.com".

\section{Conclusions}

In our knowledge, this study provides first evidence that a significant proportion of STEC isolated from healthy sheep on smallholdings in Bangladesh carrying antimicrobial resistance genes. This finding would be useful in advocating any future approach targeting source-mitigation of zoonotic pathogens to protect the public health in rural Bangladesh.

Supplementary Materials: Table S1: Variable-wise prevalence of stx1 genotype of STEC isolated from sheep in Bangladesh, Table S2: Variable-wise prevalence of stx2 genotype of STEC isolated from sheep in Bangladesh.

Author Contributions: Conceptualization, M.D.G. and A.D. (Ashutosh Das); methodology, M.D.G, A.S., M.S., A.D. (Avijit Dutta) and A.D. (Ashutosh Das); software, M.D.G and A.D. (Ashutosh Das); formal analysis, M.D.G and A.D.; investigation, M.D.G, A.S. and A.D. (Ashutosh Das); resources, M.D.G, A.S. and A.D. (Ashutosh Das); data curation, M.D.G, A.S. and A.D. (Ashutosh Das); writing-original draft preparation, M.D.G and A.D. (Ashutosh Das); writing-review and editing, M.D.G, A.S. and A.D. (Ashutosh Das); supervision, M.D.G. and A.D. (Ashutosh Das); project administration, M.D.G. and A.D. (Ashutosh Das); funding acquisition, M.D.G. and A.D. (Ashutosh Das). All authors have read and agreed to the published version of the manuscript.

Funding: This research was funded by University Grants Commission, Bangladesh, under a project entitled "Prevalence and antibiotic sensitivity of shiga toxin producing Escherichia coli in sheep, Bangladesh".

Institutional Review Board Statement: The manuscript does not contain clinical studies or patient data.

Informed Consent Statement: Not applicable.

Data Availability Statement: The data used to support the findings of this study are included in this study.

Conflicts of Interest: No conflict of interest

\section{References}

1. Cheney, T.; Smith, R.; Hutchinson, J.; Brunton, L.; Pritchard, G.; Teale, C. Cross-sectional survey of antibiotic resistance in Escherichia coli isolated from diseased farm livestock in England and Wales. Epidemiology E Infection 2015, 143, $2653-2659$.

2. Kaper, J.B.; Nataro, J.P.; Mobley, H.L. Pathogenic Escherichia coli. Nature Reviews Microbiology 2004, 2, $123-140$.

3. Nataro, J.P.; Kaper, J.B. Diarrheagenic Escherichia coli. Clinical Microbiology Reviews 1998, 11, 142-201.

4. Pitout, J. Extraintestinal pathogenic Escherichia coli: a combination of virulence with antibiotic resistance. Frontiers in Microbiology 2012, 3, 9 .

5. Byrne, L.; Jenkins, C.; Launders, N.; Elson, R.; Adak, G. The epidemiology, microbiology and clinical impact of Shiga toxinproducing Escherichia coli in England, 2009-2012. Epidemiology E Infection 2015, 143, 3475-3487.

6. Mughini-Gras, L.; Van Pelt, W.; Van der Voort, M.; Heck, M.; Friesema, I.; Franz, E. Attribution of human infections with Shiga toxin-producing Escherichia coli (STEC) to livestock sources and identification of source-specific risk factors, The Netherlands (2010-2014). Zoonoses and Public Health 2018, 65, e8-e22.

7. Fairbrother, J.; Nadeau, E. Escherichia coli: on-farm contamination of animals. Revue Scientifique et Technique 2006, $25,555-569$.

8. Jones, G.; Lefèvre, S.; Donguy, M.-P.; Nisavanh, A.; Terpant, G.; Fougère, E.; Vaissière, E.; Guinard, A.; Mailles, A.; de Valk, H. Outbreak of Shiga toxin-producing Escherichia coli (STEC) O26 paediatric haemolytic uraemic syndrome (HUS) cases associated with the consumption of soft raw cow's milk cheeses, France, March to May 2019. Eurosurveillance 2019, $24,1900305$.

9. Monaghan, Á.; Byrne, B.; Fanning, S.; Sweeney, T.; McDowell, D.; Bolton, D.J. Serotypes and virulotypes of non-O157 shigatoxin producing Escherichia coli (STEC) on bovine hides and carcasses. Food Microbiology 2012, 32, 223-229. 
10. Verhaegen, B.; Van Damme, I.; Heyndrickx, M.; Botteldoorn, N.; Elhadidy, M.; Verstraete, K.; Dierick, K.; Denayer, S.; De Zutter, L.; De Reu, K. Evaluation of detection methods for non-O157 Shiga toxin-producing Escherichia coli from food. International Journal of Food Microbiology 2016, 219, 64-70.

11. (EFSA), E.F.S.A. The European Union summary report on antimicrobial resistance in zoonotic and indicator bacteria from humans, animals and food in 2014. EFSA Journal 2016, 14, 4380.

12. Tadesse, D.A.; Zhao, S.; Tong, E.; Ayers, S.; Singh, A.; Bartholomew, M.J.; McDermott, P.F. Antimicrobial drug resistance in Escherichia coli from humans and food animals, United States, 1950-2002. Emerging Infectious Diseases 2012, 18, 741.

13. Gupta, M.; Das, A.; Islam, M.; Biswas, P. Prevalence of sorbitol non-fermenting Shiga toxin-producing Escherichia coli in Black Bengal goats on smallholdings. Epidemiology \& Infection 2016, 144, 2501-2508.

14. Gupta, M.D.; Sen, A.; Das, A. Occurrence of Escherichia coli carrying Shiga toxin-producing genes in buffaloes on smallholdings in Bangladesh. Veterinary World 2018, 11, 1454.

15. Hassan, J.; Nazir, K.N.H.; Parvej, M.S.; Kamal, T.; Rahman, M.T. Molecular based prevalence of shigatoxigenic Escherichia coli in rectal swab of apparently healthy cattle in Mymensingh district, Bangladesh. Journal of Advanced Veterinary and Animal Research 2017, 4, 194-199.

16. Islam, M.; Christensen, J.; Biswas, P. Sorbitol non-fermenting shiga toxin-producing Escherichia coli in cattle on smallholdings. Epidemiology \& Infection 2015, 143, 94-103.

17. Orden, J.; Ruiz-Santa-Quiteria, J.; Blanco, M.; Blanco, J.; Mora, A.; Cid, D.; González, E.; Blanco, J.; De la Fuente, R. Prevalence and characterization of Vero cytotoxin-producing Escherichia coli isolated from diarrhoeic and healthy sheep and goats. Epidemiology E Infection 2003, 130, 313-321.

18. Zweifel, C.; Zychowska, M.; Stephan, R. Prevalence and characteristics of Shiga toxin-producing Escherichia coli, Salmonella spp. and Campylobacter spp. isolated from slaughtered sheep in Switzerland. International Journal of Food Microbiology 2004, 92, 45-53.

19. Zschöck, M.; Hamann, H.; Kloppert, B.; Wolter, W. Shiga-toxin-producing Escherichia coli in faeces of healthy dairy cows, sheep and goats: prevalence and virulence properties. Letters in Applied Microbiology 2000, 31, 203-208.

20. Sharaf, E.F.; Shabana, I.I. Prevalence and molecular characterization of Shiga toxin-producing Escherichia coli isolates from human and sheep in Al-Madinah Al-Munawarah. Infectio 2017, 21, 81-87.

21. Milnes, A.; Stewart, I.; Clifton-Hadley, F.; Davies, R.; Newell, D.; Sayers, A.; Cheasty, T.; Cassar, C.; Ridley, A.; Cook, A. Intestinal carriage of verocytotoxigenic Escherichia coli O157, Salmonella, thermophilic Campylobacter and Yersinia enterocolitica, in cattle, sheep and pigs at slaughter in Great Britain during 2003. Epidemiology \& Infection 2008, 136, 739-751.

22. Battisti, A.; Lovari, S.; Franco, A.; Di Egidio, A.; Tozzoli, R.; Caprioli, A.; Morabito, S. Prevalence of Escherichia coli O157 in lambs at slaughter in Rome, central Italy. Epidemiology \& Infection 2006, 134, 415-419.

23. Reid, C.-A.; Small, A.; Avery, S.; Buncic, S. Presence of food-borne pathogens on cattle hides. Food control 2002, 13, 411-415.

24. Wani, S.; Samanta, I.; Munshi, Z.; Bhat, M.; Nishikawa, Y. Shiga toxin-producing Escherichia coli and enteropathogenic Escherichia coli in healthy goats in India: occurrence and virulence properties. Journal of Applied Microbiology 2006, 100, 108-113.

25. McCarthy, S.; Macori, G.; Burgess, C.; Fanning, S.; Duffy, G. Surveillance of Shiga-toxin producing Escherichia coli in Irish sheep. Access Microbiology 2019, 1, 821.

26. Johura, F.-T.; Parveen, R.; Islam, A.; Sadique, A.; Rahim, M.N.; Monira, S.; Khan, A.R.; Ahsan, S.; Ohnishi, M.; Watanabe, H. Occurrence of hybrid Escherichia coli strains carrying Shiga toxin and heat-stable toxin in livestock of Bangladesh. Frontiers in Public Health 2017, 4, 287.

27. Gupta, M.; Das, A.; Ahad, A.; Biswas, P. Antimicrobial susceptibility pattern of sorbitol non-fermenting including Shiga toxin producing Escherichia coli isolated from black Bengal goat. Bangladesh Journal of Veterinary and Animal Sciences 2013, 2, 8-13.

28. Islam, M.Z.; Ahad, A.; Biswas, P.K. Antimicrobial resistance profile of sorbitol non-fermenting Shiga toxin producing Escherichia coli isolated from smallholdings cattle. Journal of Infection and Molecular Biology 2013, 1, 58-63.

29. Sandle, T. Antibiotics and preservatives. Pharmaceutical Microbiology 2016, 171-183.

30. Ma, F.; Xu, S.; Tang, Z.; Li, Z.; Zhang, L. Use of antimicrobials in food animals and impact of transmission of antimicrobial resistance on humans. Biosafety and Health 2020, 3, 32-38.

31. Oppegaard, H.; Steinum, T.M.; Wasteson, Y. Horizontal transfer of a multi-drug resistance plasmid between coliform bacteria of human and bovine origin in a farm environment. Applied and Environmental Microbiology 2001, 67, 3732-3734.

32. Lerminiaux, N.A.; Cameron, A.D. Horizontal transfer of antibiotic resistance genes in clinical environments. Canadian Journal of Microbiology 2019, 65, 34-44.

33. Gupta, M.D.; Islam, M.; Sen, A.; Sarker, M.S.; Das, A. Prevalence and antibiotic susceptibility pattern of Escherichia coli in cattle on Bathan and intensive rearing system. Microbes and Health 2017, 6, 1-4.

34. DesRosiers, A.; Fairbrother, J.M.; Johnson, R.P.; Desautels, C.; Letellier, A.; Quessy, S. Phenotypic and genotypic characterization of Escherichia coli verotoxin-producing isolates from humans and pigs. Journal of Food Protection 2001, 64, $1904-1911$.

35. Manna, S.; Brahmane, M.; Das, R.; Chandana, M.; Batabyal, S. Detection of Escherichia coli O157 in foods of animal origin by culture and multiplex polymerase chain reaction. Journal of Food Science and Technology-Mysore 2006, 43, 77-79.

36. Bauer, A.t. Antibiotic susceptibility testing by a standardized single disc method. American Journal of Clinical Pathology 1966, 45, 149-158.

37. Altschul, S.F.; Gish, W.; Miller, W.; Myers, E.W.; Lipman, D.J. Basic local alignment search tool. Journal of Molecular Biology 1990, $215,403-410$. 
38. Belaaouaj, A.; Lapoumeroulie, C.; Caniça, M.M.; Vedel, G.; Névot, P.; Krishnamoorthy, R.; Paul, G. Nucleotide sequences of the genes coding for the TEM-like $\beta$-lactamases IRT-1 and IRT-2 (formerly called TRI-1 and TRI-2). FEMS Microbiology Letters 1994, $120,75-80$.

39. Sunde, M. Prevalence and characterization of class 1 and class 2 integrons in Escherichia coli isolated from meat and meat products of Norwegian origin. Journal of Antimicrobial Chemotherapy 2005, 56, 1019-1024.

40. Chang, L.-L.; Lin, H.-H.; Chang, C.-Y.; Lu, P.-L. Increased incidence of class 1 integrons in trimethoprim/sulfamethoxazoleresistant clinical isolates of Stenotrophomonas maltophilia. Journal of Antimicrobial Chemotherapy 2007, 59, 1038-1039. 